\title{
Clinical characteristics and epidemiology of chronic urticaria: a nationwide, multicentre study on 1091 patients
}

\author{
Alina Jankowska-Konsur ${ }^{1}$, Adam Reich ${ }^{1,2}$, Jacek Szepietowski'; the Polish Chronic Urticaria Working Group
}

${ }^{1}$ Department of Dermatology, Venereology and Allergology, Wroclaw Medical University, Wroclaw, Poland ${ }^{2}$ Department of Dermatology, University of Rzeszow, Rzeszow, Poland

Adv Dermatol Allergol 2019; XXXVI (2): 184-191 DOI: https://doi.org/10.5114/ada.2019.84594

\begin{abstract}
Introduction: Urticaria is one of the most common skin diseases. Depending on the length of symptoms, acute (lasting less than 6 weeks) and chronic urticaria (CU) (> 6 weeks) are distinguished. According to the current European guidelines, CU is divided into inducible urticaria (IU) and chronic spontaneous urticaria (CSU).

Aim: To assess the epidemiology and clinical characteristics of CU in Poland.

Material and methods: This was a nationwide, multicentre, cross-sectional, questionnaire-based study performed under the auspices of the Polish Dermatological Society. A total of 102 physicians (dermatologists and allergists) recruited 1091 patients suffering from CU.

Results: Among 1091 adults with CU, IU was found in 35.1\% $(n=383)$ of patients and CSU was responsible for $61.1 \%$ ( $n=667)$ of CU cases. The remaining patients $(n=41,3.8 \%)$ suffered from both, IU and CSU. Persons with CSU were twice more likely to report family history of urticaria than those with IU (12.1\% vs. $6.0 \%, p=0.001)$. Generalized eruptions of wheals predominated in CSU (generalized wheals: $57.9 \%$, localized wheals: $42.1 \%$ ), whereas wheals localized in particular body areas were found more commonly in IU (generalized wheals: $45.2 \%$, localized wheals: $54.8 \%, p<0.001)$. The CU was the cause of absenteeism in almost every fifth patient suffering from this disease. Conclusions: The CSU is about twice as frequent cause of CU as compared to IU. The treatment of CU is a major challenge for physicians of various specialties and the treatment choice is closely associated with the specialist knowledge of current treatment guidelines.
\end{abstract}

Key words: inducible urticaria, chronic spontaneous urticaria, allergic diseases.

\section{Introduction}

Urticaria is a common disease characterized by sudden development of wheals, angioedema or both [1]. Chronic urticaria (CU) manifests by reoccurrence of typical lesions for at least 6 weeks or longer and affects up to $1 \%$ of general population at any given time [2, 3]. According to the latest EAACI/GA²LN/EDF/WAO guidelines, it can be classified either as a spontaneous subtype (CSU) or as an inducible subtype, triggered mostly by physical factors (inducible urticaria - IU) [1]. Epidemiological data on CU, especially its clinical and demographic determinants as well as health care system patterns, are still scarce in the literature.

\section{Aim}

The aim of this large, nationwide, multicentre study was to provide more insights regarding the demographic data, clinical manifestations, disease activity/damage, laboratory abnormalities and treatment of urticaria in the Polish population.

\section{Material and methods}

This nationwide, multicentre, cross-sectional questionnaire-based study was performed under the auspices of the Polish Dermatological Society. A total of 108 physicians dealing with patients suffering from allergic diseases were invited to participate in the study. All participating physicians were asked to recruit 10 consecutive patients suffering from chronic urticaria. Physicians were invited from different regions of Poland to achieve a good representation of patients from the whole Poland. Six (5.6\%) invited physicians refused to participate. The remaining 102 (94.4\%) physicians (dermatologists and

Address for correspondence: Prof. Jacek C. Szepietowski, Department of Dermatology, Venereology and Allergology, Wroclaw Medical University, 1 Chałubińskiego St, 50-368 Wroclaw, Poland, phone: +48 7178422 86, fax: +48 7132709 42, e-mail: Jacek.szepietowski@umed.wroc.pl Received: 17.12.2017, accepted: 30.01.2018. 
allergists) recruited a total of 1091 patients with CU. The study was approved by the Ethics Committee at the Wroclaw Medical University and was performed in accordance with the principles of the Declaration of Helsinki. All patients agreed voluntarily to participate in the study.

The 27-item semi-open questionnaire was completed for each patient based on medical history and physical examination during a routine outpatient consultation (Appendix 1). Questions referred to epidemiological data, clinical characteristics of urticaria, as well as management, treatment and outcome of the disease. For the study purpose we used the EAACI/GA ${ }^{2}$ LEN/EDF/WAO guidelines for the definition, classification and diagnosis of urticaria (2013 update) [1].

\section{Statistical analysis}

Statistical analysis of all data was performed using Statistica 12.0 software (Dell Software, USA). Differences between compared patient groups were verified using $\chi^{2}$ test with Yates correction, if necessary. Correlation data were analysed by Spearman rank correlations test. Values of $p<0.05$ were considered statistically significant.

\section{Results}

A total of 1091 adults (709 women and 382 men) with CU have been included into the study. Regarding their age, 74 (6.8\%) patients were below the age of 20 years, 231 (21.2\%) were aged between 21 and 30 years, $263(24.1 \%)-31-40$ years, $211(19.3 \%)-41-50$ years, $158(14.5 \%)-51-60$ years, $127(11.6 \%)-61-70$ years, 22 $(2.0 \%)-71-80$ years and remaining $5(0.5 \%)$ were older than 80 years. IU was diagnosed in $35.1 \%(n=383$ : 235 women, 148 men), while CSU in $61.1 \%$ of patients ( $n=667$ : 442 women, 225 men), however, $3.8 \%$ of participants ( $n=41$ : 32 women, 9 men) had both CSU and IU.

Among IU patients the most common types of urticaria were factitious urticaria $(n=128 ; 11.7 \%)$, cholinergic urticaria ( $n=83,7.6 \%$ ), delayed pressure urticaria $(n=44,4.0 \%)$, solar urticaria $(n=38,3.5 \%)$ and cold urticaria ( $n=33,3.0 \%)$. No significant differences were observed between women and men regarding the subtype of IU, except cholinergic urticaria which was significantly more prevalent among men $(n=62,16.2 \%)$ compared to women $(n=21,3.0 \%)(p<0.001)$. The exact epidemiologic and clinical data are collected in Table 1.

Among patients with CU, 517 (47.4\%) subjects also suffered from other allergic diseases, sometimes having even more than one such disease (allergic rhinitis $n=326$, bronchial asthma $-n=138$, atopic dermatitis $n=108$, nutrition allergy $-n=62$ ). Taking into account the course of the disease we found that the daily occurrence of new wheals was slightly more common in IU than in CSU, but the difference was not significant $(p=0.09)$. However, the wheals in IU resolved faster than in CSU patients $(p<0.001)$ (Table 1$)$. In contrast, the le- sions in CSU were usually more widespread $(p<0.001)$ and were also more commonly accompanied by angioedema $(p<0.05)$ (for details see Table 1$)$. An average number of medical consultations/year due to urticaria was $3.0 \pm 1.7$ in CSU and $2.9 \pm 1.8$ in IU $(p=0.36)$. Patients considered pruritus (75.8\%), followed by the presence of skin lesions (35.9\%), burning sensations (23.6\%) and angioedema (13.3\%) to be the most bothersome symptoms of urticaria. Patients with the first episode of urticaria sought help primarily from general practitioners (52.9\%), followed by dermatologists (25.5\%) and internal medicine specialists (14.1\%). Allergists and dermatologists were the most common specialists $38.6 \%$ and $33.0 \%$, respectively) to whom patients were referred to by other physicians. The disease diagnosis was established predominantly by dermatologists (52.7\%) and allergists (43.1\%). Analysing the medication pattern we noticed that the second generation of antihistamines were used most commonly as the first-line treatment, followed by the first generation of antihistamines, regardless of the type of CU (Table 2).

Antihistamines were used significantly more frequently in the registered dose in the IU group, while in the CSU group antihistamines were used significantly more often in higher doses than the registered ones ( $p<0.01$ for both comparisons). Short-term systemic steroids were used in $53.2 \%$ of patients with CSU and in $39.4 \%$ with IU, and the difference was statistically significant $(p<0.001)$. Regarding the treatment outcomes, complete resolution of skin symptoms was observed in $33.4 \%$ of $\mathrm{CU}$ patients (32.7\% in CSU, 36.0\% in IU). The CU was the cause of absence from work in $16.3 \%$ of patients, of whom $45.5 \%$ had the sick leave of between 6 and 14 days, $26.4 \%$ of patients were on sick leave for 15 to 30 days and $14.6 \%$ of patients were absent from work due to CU for more than a month.

\section{Discussion}

Our study provides a number of new epidemiological data concerning CU. As to the aetiology, CSU represents more than $60 \%$ of all cases of CU. These results are consistent with data published previously (70-82\% of the cases) [4-7]. Inducible urticaria occurred in approximately one third of patients, however, its prevalence varies greatly among the studies from 10\% even to almost 100\% [8-11]. As has been previously reported, we observed a significantly higher prevalence (65\%) of urticaria in women, which can be partially explained by a higher incidence of autoimmune diseases in women than in men $[8,12]$. On the other hand, cholinergic urticaria was significantly more common in men. Other studies provide inconsistent data concerning the sex in this subset of urticaria. The study of Kim et al. [13] showed a male predominance, while others have reported that both sexes were affected to the same degree $[14,15]$. 
Table 1. Epidemiological and clinical data of the patients with chronic urticaria

\begin{tabular}{|c|c|c|c|c|}
\hline Parameter & CSU & IU & CSU and IU & $P$-value \\
\hline \multicolumn{5}{|l|}{ Sex: } \\
\hline Males & $225(33.7 \%)$ & $148(38.6 \%)$ & $9(22.0 \%)$ & \multirow[t]{2}{*}{0.06} \\
\hline Females & $442(66.3 \%)$ & $235(61.4 \%)$ & $32(78.0 \%)$ & \\
\hline \multicolumn{5}{|l|}{ Age [years]: } \\
\hline$\leq 20$ & $35(5.2 \%)$ & $38(9.2 \%)$ & $1(2.4 \%)$ & \multirow[t]{8}{*}{0.03} \\
\hline $21-30$ & $132(19.8 \%)$ & $92(24.0 \%)$ & $7(17.1 \%)$ & \\
\hline $31-40$ & $165(24.7 \%)$ & $86(22.5 \%)$ & $12(29.3 \%)$ & \\
\hline $41-50$ & $131(19.6 \%)$ & $73(19.1 \%)$ & 7 (17.1\%) & \\
\hline $51-60$ & $100(15.0 \%)$ & $48(12.5 \%)$ & $10(24.4 \%)$ & \\
\hline $61-70$ & 89 (13.3\%) & $35(9.1 \%)$ & $3(7.3 \%)$ & \\
\hline $71-80$ & $14(2.1 \%)$ & $7(1.8 \%)$ & $1(2.4 \%)$ & \\
\hline$\geq 81$ & $1(0.1 \%)$ & $4(1.0 \%)$ & $0(0 \%)$ & \\
\hline \multicolumn{5}{|l|}{ Concomitant allergic diseases: } \\
\hline Allergic rhinitis & $211(31.6 \%)$ & $102(26.6 \%)$ & $13(31.7 \%)$ & 0.23 \\
\hline Bronchial asthma & 89 (13.3\%) & $46(12.0 \%)$ & $3(7.3 \%)$ & 0.48 \\
\hline Atopic dermatitis & 68 (10.2\%) & 37 (9.7\%) & $3(7.3 \%)$ & 0.82 \\
\hline Food allergy & $45(6.7 \%)$ & $14(3.7 \%)$ & $3(7.3 \%)$ & 0.1 \\
\hline \multicolumn{5}{|l|}{ Family history of urticaria: } \\
\hline Yes & $78(11.7 \%)$ & $23(6.0 \%)$ & $8(19.5 \%)$ & \multirow[t]{2}{*}{0.001} \\
\hline No & $589(88.3 \%)$ & $360(94.0 \%)$ & $33(80.5 \%)$ & \\
\hline \multicolumn{5}{|l|}{ Frequency of wheal outbreaks: } \\
\hline Every day & $73(10.9 \%)$ & $66(17.2 \%)$ & $6(14.6 \%)$ & \multirow[t]{5}{*}{0.09} \\
\hline Several times a week & $116(17.4 \%)$ & 69 (18.0\%) & $6(14.6 \%)$ & \\
\hline Several times a month & $186(27.9 \%)$ & $89(23.2 \%)$ & $8(19.5 \%)$ & \\
\hline Once a month & $140(21.0 \%)$ & $62(16.2 \%)$ & $8(19.5 \%)$ & \\
\hline Less than once a month & $146(21.9 \%)$ & $88(23.0 \%)$ & $11(26.8 \%)$ & \\
\hline \multicolumn{5}{|l|}{ Extent of the skin lesions: } \\
\hline Localized & $266(39.9 \%)$ & $210(54.8 \%)$ & $16(39.0 \%)$ & \multirow[t]{2}{*}{$<0.001$} \\
\hline Generalized & $387(58.0 \%)$ & $163(42.6 \%)$ & $23(56.1 \%)$ & \\
\hline \multicolumn{5}{|l|}{ Swelling of the tongue and/or lips: } \\
\hline Yes & $181(27.1 \%)$ & $88(23.0 \%)$ & $14(34.1 \%)$ & \multirow[t]{2}{*}{$<0.05$} \\
\hline No & $481(72.1 \%)$ & $290(75.7 \%)$ & 25 (61.0\%) & \\
\hline \multicolumn{5}{|l|}{ Duration of the urticaria episode: } \\
\hline A few minutes & $67(10.0 \%)$ & $103(26.9 \%)$ & $4(9.8 \%)$ & \multirow[t]{4}{*}{$<0.001$} \\
\hline A few hours & $373(55.9 \%)$ & $195(50.9 \%)$ & $21(51.2 \%)$ & \\
\hline All day & $117(17.5 \%)$ & $46(12.0 \%)$ & $9(22.0 \%)$ & \\
\hline A few days & $108(16.2 \%)$ & $37(9.7 \%)$ & $5(12.2 \%)$ & \\
\hline \multicolumn{5}{|l|}{ The most troublesome symptoms: } \\
\hline Pruritus & $513(76.9 \%)$ & $288(75.2 \%)$ & $26(63.4 \%)$ & 0.14 \\
\hline Burning & $161(24.1 \%)$ & $82(21.4 \%)$ & $15(36.6 \%)$ & 0.08 \\
\hline The presence of the skin lesions & $241(36.1 \%)$ & $135(35.2 \%)$ & $16(39.0 \%)$ & 0.88 \\
\hline Swelling of the tongue and lips & 82 (12.3\%) & 55 (14.4\%) & 8 (19.5\%) & 0.31 \\
\hline
\end{tabular}

CSU - chronic spontaneous urticaria, IU - inducible urticaria. 
Table 2. Treatment regimens and outcomes in chronic urticaria

\begin{tabular}{|c|c|c|c|c|}
\hline Variable & CSU & IU & CSU and IU & $P$-value \\
\hline \multicolumn{5}{|l|}{ Treatment at first diagnosis: } \\
\hline First-generation antihistamines & $255(38.2 \%)$ & $125(32.6 \%)$ & $16(39.0 \%)$ & 0.18 \\
\hline Second-generation antihistamines & $522(78.3 \%)$ & $285(74.4 \%)$ & 25 (61.0\%) & 0.02 \\
\hline $\mathrm{H}_{2}$ antagonists & $40(6.0 \%)$ & $23(6.0 \%)$ & $4(9.8 \%)$ & 0.62 \\
\hline Leukotriene receptor antagonist & $45(6.7 \%)$ & $15(3.9 \%)$ & $1(2.4 \%)$ & 0.11 \\
\hline Corticosteroids & $229(34.3 \%)$ & $94(24.5 \%)$ & $13(31.7 \%)$ & $<0.01$ \\
\hline Cyclosporine A & $8(1.2 \%)$ & $1(0.3 \%)$ & $1(2.4 \%)$ & 0.18 \\
\hline \multicolumn{5}{|l|}{ Treatment in the past: } \\
\hline First-generation antihistamines & $421(63.1 \%)$ & $212(55.4 \%)$ & 27 (65.9\%) & 0.04 \\
\hline Second-generation antihistamines & $603(90.4 \%)$ & $332(86.7 \%)$ & $30(73.2 \%)$ & 0.001 \\
\hline $\mathrm{H}_{2}$ antagonists & $119(17.8 \%)$ & $50(13.1 \%)$ & $17(41.5 \%)$ & $<0.001$ \\
\hline Leukotriene receptor antagonist & $108(16.2 \%)$ & $58(15.1 \%)$ & $7(17.1 \%)$ & 0.88 \\
\hline Corticosteroids & $355(53.2 \%)$ & $151(39.4 \%)$ & $21(51.2 \%)$ & $<0.001$ \\
\hline Cyclosporine A & $22(3.3 \%)$ & $7(1.8 \%)$ & $2(4.9 \%)$ & 0.28 \\
\hline \multicolumn{5}{|l|}{ Antihistamine dosage: } \\
\hline Registered doses & $334(50.1 \%)$ & $218(56.9 \%)$ & $12(29.3 \%)$ & 0.001 \\
\hline Doses higher than registered & $330(49.5 \%)$ & $167(43.6 \%)$ & $28(68.3 \%)$ & $<0.01$ \\
\hline Dose twice higher than registered & $194(29.1 \%)$ & $114(29.8 \%)$ & $17(41.5 \%)$ & 0.24 \\
\hline Dose three times higher than registered & $47(7.0 \%)$ & $18(4.7 \%)$ & $2(4.9 \%)$ & 0.29 \\
\hline Dose four times higher than registered & 99 (14.8\%) & 40 (10.4\%) & $10(24.4 \%)$ & 0.02 \\
\hline \multicolumn{5}{|l|}{ Efficacy of the treatment: } \\
\hline Resolution of the symptoms & $218(32.7 \%)$ & $138(36.0 \%)$ & $8(19.5 \%)$ & 0.08 \\
\hline Reduction of the symptoms & $320(48.0 \%)$ & $178(46.5 \%)$ & $20(48.8 \%)$ & \\
\hline Slight improvement & $107(16.0 \%)$ & $42(11.0 \%)$ & $9(22.0 \%)$ & \\
\hline No effect & $11(1.7 \%)$ & $11(2.8 \%)$ & $1(2.4 \%)$ & \\
\hline Not applicable & $4(0.6 \%)$ & $5(1.3 \%)$ & $1(2.4 \%)$ & \\
\hline \multicolumn{5}{|l|}{ Absenteeism at work: } \\
\hline No & $552(82.8 \%)$ & $331(86.4 \%)$ & 30 (73.2\%) & 0.05 \\
\hline Yes & $115(17.2 \%)$ & $52(13.6 \%)$ & $11(26.8 \%)$ & \\
\hline \multicolumn{5}{|l|}{ (if yes, how many days/year?): } \\
\hline $1-5$ days & $24(3.6 \%)$ & $14(3.7 \%)$ & $3(7.3 \%)$ & \\
\hline $6-10$ days & $25(3.7 \%)$ & $13(3.4 \%)$ & $3(7.3 \%)$ & \\
\hline 11-14 days & $30(4.5 \%)$ & $8(2.1 \%)$ & $2(4.9 \%)$ & \\
\hline 15-20 days & $13(1.9 \%)$ & $7(1.8 \%)$ & $2(4.9 \%)$ & \\
\hline $21-30$ days & $14(2.1 \%)$ & $9(2.3 \%)$ & $2(4.9 \%)$ & \\
\hline$>30$ & $17(2.5 \%)$ & $8(2.1 \%)$ & $1(2.4 \%)$ & \\
\hline
\end{tabular}

CSU - chronic spontaneous urticaria, IU - inducible urticaria.

Compared to the general population, wherein the average prevalence of allergic rhinitis is approximately $25 \%$, the prevalence of allergic rhinitis in CU patients seems to be higher [16]. Food allergy was reported in $5.7 \%$ of patients. Similarly, in Kulthanan's paper food allergy was found in $4 \%$ of the patients with CU [17]. The impact of nutrients on chronic urticaria is not entirely understood. It is believed that pseudoallergic reactions or aspirin idiosyncrasy are more likely to occur in CU, whereas IgEmediated reactions may play a role in acute urticaria.

Chronic urticaria significantly impairs quality of life of the patients. In the analysed group the most trouble- 
some symptom of the disease was pruritus, followed by the presence of skin lesions. Other studies confirm our results showing itching as the leading bothersome symptom of CU [12].

In our report we also examined the utilization of the healthcare system pattern. In the analysed group more than a half of all patients sought help from the general practitioners in the first place. However, in order to establish the precise diagnosis and treatment, $71.6 \%$ of the patients were subsequently referred to allergists and dermatologists. These data reflect the mechanism of functioning of the health care system in Poland, where the family doctor does not have the appropriate tools for detailed diagnosis of urticaria. In addition, patients need a referral to a specialist and the time to see a specialist is much longer than to see a family doctor. A similar proceeding pattern was observed in Spanish population, but in contrast to our study, a large proportion of Spanish patients were treated in emergency departments [8].

The treatment of CU is a major challenge for physicians of various specialties. Numerous studies pointed the usefulness of the second-generation $\mathrm{H} 1$-antihistamines as the first-line treatment of $\mathrm{CU}$ and, as also shown in our study, this was the therapy of choice for the majority of physicians, regardless of the specialty. Surprisingly, more than one-third of physicians choose the sedative first-generation $\mathrm{H} 1$-antihistamines and systemic steroids alone or in combination as the initial therapy. A similar drug administration pattern was reported by Weller et al. [18] who found that approximately $20 \%$ of German specialists (mainly dermatologists and allergists) were using the first-generation $\mathrm{H} 1$-antihistamines or steroids as the first-line treatment for CU. On the other hand, according to a large multicentre study conducted among Italian specialists (dermatologists and allergists) it was demonstrated that second-generation $\mathrm{H}_{1}$-antihistamines in the registered dose were the most common treatment of choice in Italy [19]. The authors of both studies indicated that the treatment choice was closely associated with the specialist knowledge of current treatment guidelines.

Taking into account the type of CU, we noticed that both, the second-generation $\mathrm{H1}$-antihistamines in higher than registered doses as well as systemic steroids were prescribed significantly more often in CSU than in IU, which may mirror the physicians' conviction that this variant of urticaria is more difficult to control by standard regimen. In our study, the applied treatment induced complete remission of skin lesions in up to $40 \%$ of patients and significant remission of the symptoms was observed in further $47.5 \%$. However, in CU, treatment results are frequently unsatisfactory, both for doctors and patients [20]. In our study, $16.6 \%$ of patients demonstrated no improvement after the treatment or the remission was inconsiderable.

\section{Conclusions}

Chronic urticaria constitutes a significant economic burden on society in terms of the absence from work and production lost. According to our data, urticaria was the cause of absenteeism in almost every fifth patient suffering from CU. In contrast, in Spanish population, only $8.7 \%$ of patients seeking medical attention due to urticaria, required an absence from work [8]. Numerous data indicated that the use of antihistamines in the registered doses allows symptom reduction in less than $50 \%$ of CSU patients, and increased dosage of these drugs increases the proportion of responders [18, 21, 22]. However, there is a group of patients in whom it is difficult to obtain satisfactory improvement. In our study there were no patients treated with omalizumab, because the drug is still difficult to obtain in Poland and it is not routinely used, but we suspect that the wider use of omalizumab in selected patients could further improve the treatment results.

\section{Acknowledgments}

The authors would like to thank all physicians who agreed to participate in this study. This study was supported by the unrestrictive educational grant provided by Novartis Poland.

\section{Conflict of interest}

This study was supported by an educational grant provided by Novartis Poland.

\section{References}

1. Zuberbier T, Aberer W, Asero R, et al. The EAACI/GA(2) LEN/ EDF/WAO Guideline for the definition, classification, diagnosis, and management of urticaria: the 2013 revision and update. Allergy 2014; 69: 868-87.

2. Greaves M. Chronic urticaria. J Allergy Clin Immunol 2000; 105: 664-72.

3. Gaig P, Olona M, Muńoz Lejarazu D, et al. Epidemiology of urticaria in Spain. J Investig Allergol Clin Immunol 2004; 14 : 214-20.

4. Kulthanan K, Jiamton S, Thumpimukvatana N, Pinkaew S. Chronic idiopathic urticaria: prevalence and clinical course. J Dermatol 2007; 34: 294-301.

5. Champion RH. Urticaria: then and now. Br J Dermatol 1988; 119: 427-36.

6. Green GA, Koelsche GA, Kierland R. Etiology and pathogenesis of chronic urticaria. Ann Allergy 1965; 23: 30-6.

7. Champion RH, Roberts SO, Carpenter RG, Roger JH. Urticaria and angio-oedema. A review of 554 patients. Br J Dermatol 1969, 81: 588-97.

8. Ferrer M. Epidemiology, healthcare, resources, use and clinical features of different types of urticaria. Alergologica 2005. J Investig Allergol Clin Immunol 2009; 19 Suppl 2: 21-6.

9. Kozel MM, Mekkes JR, Bossuyt PM, Bos JD. Natural course of physical and chronic urticaria and angioedema in 220 patients. J Am Acad Dermatol 2001; 45: 387-91. 
10. Nettis E, Pannofino A, D'Aprile C, et al. Clinical and aetiological aspects in urticaria and angio-oedema. Br J Dermatol 2003; 148: 501-6.

11. Sibbald RG, Cheema AS, Lozinski A, Tarlo S. Chronic urticaria. Evaluation of the role of physical, immunologic, and other contributory factors. Int I Dermatol 1991; 30: 381-6.

12. Gattey N, Bahrani B, Hull PR. Chronic spontaneous urticaria: a questionnaire survey. J Cutan Med Surg 2016; 20: 241-3.

13. Kim JE, Eun YS, Park YM, et al. Clinical characteristics of cholinergic urticaria in Korea. Ann Dermatol 2014; 26: 189-94.

14. Zuberbier T, Althaus C, Chantraine-Hess S, et al. Prevalence of cholinergic urticaria in young adults. J Am Acad Dermatol 1994; 31: 978-81.

15. Godse K, Farooqui S, Nadkarni N, et al. Prevalence of cholinergic urticaria in Indian adults. Indian Dermatol Online J 2013; 4: 62-3.

16. Samoliński B. Alergiczny nieżyt nosa w świetle badania ECAP. Alergia 2009, 2: 41-4.

17. Kulthanan K, Jiamton S, Rutnin NO, et al. Prevalence and relevance of the positivity of skin prick testing in patients with chronic urticaria. J Dermatol 2008; 35: 330-5.

18. Weller K, Viehmann K, Brautigam M, et al. Management of chronic spontaneous urticaria in real life - in accordance with the guidelines? A cross-sectional physician-based survey study. J Eur Acad Dermatol Venereol 2013; 27: 43-50.

19. Rimoldi M, Rossi O, Rota N. State of the art of chronic spontaneous urticaria in Italy: a multicentre survey to evaluate physicians' and patients' perspectives. BMJ Open 2016; 6: e012378.

20. Maurer M, Weller K, Bindslev-Jensen C, et al. Unmet clinical needs in chronic spontaneous urticaria. A GA²LEN task force report. Allergy 2011; 66: 317-30.

21. Sánchez-Borges M, Caballero-Fonseca F, Capriles-Hulett A. Treatment of recalcitrant chronic urticaria with nonsedating antihistamines: is there evidence for updosing? J Investig Allergol Clin Immunol 2013; 23: 141-4.

22. Weller K, Ziege C, Staubach P, et al. H1-antihistamine updosing in chronic spontaneous urticaria: patients'perspective of effectiveness and side effects - a retrospective survey study. PLoS One 2011; 6: e23931. 


\section{Appendix 1 \\ Questionnaire on chronic idiopathic urticaria}

Data about the patient:

Age, sex: .

1. Diagnosis:
$\square$ Chronic physical urticaria
$\square$ Heat urticaria
$\square$ Symptomatic dermographism
$\square$ Solar urticaria
$\square$ Delayed pressure urticaria
$\square$ Cholinergic urticaria
$\square$ Cold urticaria
$\square$ Other urticaria type

2. Co-existing allergic diseases:

$\square$ Asthma $\square$ Atopic dermatitis $\square$ Allergic rhinitis $\square$ Food allergy $\square$ Other chronic immunological diseases

3. Other comorbidities (please specify):

4. Drugs used chronically, how long and for what reason?

5. Does/did the patient smoke cigarettes?

$\square$ Yes - number of pack-years

$\square$ No

6. Urticaria in the family:

$\square$ Yes (specify family member)

$\square$ No

7. Allergic immune diseases in the family (who and what disease?)

8. How long has the patient sufferred from urticaria?

9. How much time has elapsed since the first symptoms of the disease appeared before the patient came to the doctor?

10. What specialist did the patient see first?

$\square$ General practitioner $\square$ Internal diseases specialist $\square$ Dermatologist $\square$ Allergist

$\square$ Other specialties (specify)

11. Did the doctor to whom the patient came in the first place, send him to another specialist?

$\square$ Yes (specify)

$\square$ No

12. Who diagnosed urticaria and started the treatment?

$\square$ General practitioner $\square$ Internal diseases specialist $\square$ Dermatologist $\square$ Allergist

$\square$ Other specialties (specify)

13. What was the time between the appearance of first symptoms and the correct diagnosis?

14. Were there any diagnostic tests performed in order to establish the diagnosis of urticaria?

$\square$ Yes $\quad \square$ No

$\square$ If yes, please specify:

$\square$ Prick tests $\square$ Specific lgE level $\square$ Patch tests

$\square$ Peripheral blood count $\square$ Serum autoantibodies $\square$ Physical tests

$\square$ Autologous serum skin tests $\square$ Aspirin provocation test

$\square$ Other (specify)

15. Was the patient hospitalized due to urticaria?
$\square$ Yes
$\square$ No

If yes, how many times? 
16. Was the patient on sick leave due to urticaria?

$\square$ Yes. If yes, how many days a year? No

17. Was the urticaria accompanied by swelling of the lips, tongue or eyelids? $\square$ Yes

$\square$ No

18. How often does urticaria appear?

$\square$ Once $\square$ Every day $\square$ At least several times a week $\square$ At least several times a month $\square$ At least once a month

$\square$ Less than once a month

19. What is the extent of the wheals?

$\square$ Wheals on a limited area of the skin (e.g. one limb, abdomen, back)

$\square$ Wheals are spread on the skin of the whole body

20. How long does the episode of urticaria last?

$\square$ A few minutes $\square$ A few hours $\square$ Whole day $\square$ A few days

21. What is the patient's most bothersome symptom of urticaria?

$\square$ Pruritus $\square$ Burning sensation $\square$ The presence of the lesions

$\square$ Other (specify)

22. Is the episode of urticaria accompanied by symptoms from other organs?

$\square$ Yes. If yes, which ones? $\square$ No

23. Which medications were used at the time of urticaria diagnosis?

$\square 1^{\text {st }}$ generation antihistamines

$\square \mathrm{H}_{2}$ antagonists (e.g. ranitidine, cimetidine)

$\square$ Corticosteroids

$\square$ Other immunosuppressive drugs

$\square 2^{\text {nd }}$ generation antihistamines

$\square$ Leukotriene receptor antagonists

$\square$ Cyclosporine A

$\square$ Other drugs (specify)

24. Which medications have been used for the treatment of hives?

$\square 1^{\text {st }}$ generation antihistamines

$\square \mathrm{H}_{2}$ antagonists (e.g. ranitidine, cimetidine)

$\square 2^{\text {nd }}$ generation antihistamines

Corticosteroids

$\square$ Leukotriene receptor antagonists

$\square$ Other immunosuppressive drugs

$\square$ Cyclosporine A

$\square$ Other drugs (specify)

25. Which medications for urticaria are used at present?
$\square 1^{\text {st }}$ generation antihistamines
$\square \mathrm{H}_{2}$ antagonists (e.g. ranitidine, cimetidine)
$\square$ Corticosteroids
$\square$ Other immunosuppressive drugs

$2^{\text {nd }}$ generation antihistamines

$\square$ Leukotriene receptor antagonists

$\square$ Cyclosporine A

$\square$ Other drugs (specify)

26. If the patient used antihistamines:

$\square$ Antihistamines were used in registered doses

$\square$ Antihistamines were used at doses higher than the registered doses:

$\square$ Twice higher dose than the registered dose

$\square$ Three times higher dose than the registered dose

$\square$ Four times higher dose than the registered dose

27. Does the medical treatment result in clinical improvement?

$\square$ Yes, it results in complete resolution of urticaria symptoms

$\square$ Yes, it significantly reduces the symptoms of urticaria

$\square$ Yes, but the improvement is small

$\square$ No, the medical treatment does not affect the course of disease 